\title{
Advanced Fuels Campaign Cladding \& Coatings Meeting Summary
}

Lori Braase Shannon Bragg-Sitton

March 2013

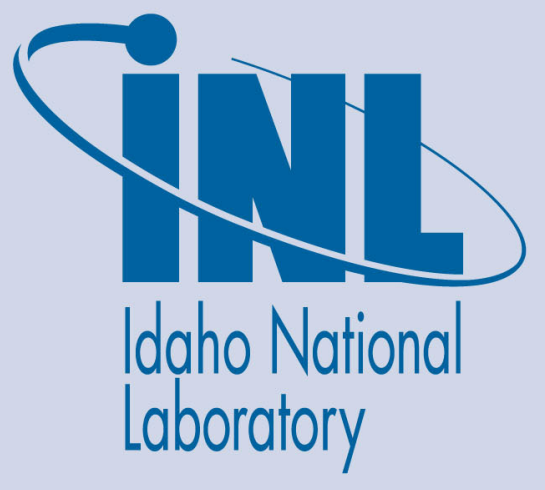

The INL is a U.S. Department of Energy National Laboratory operated by Battelle Energy Alliance 
INL/EXT-13-28628

FCRD-FUEL-2013-000114

\title{
Advanced Fuels Campaign Cladding \& Coatings Meeting Summary
}

Lori Braase

Shannon Bragg-Sitton

March 2013

\author{
Idaho National Laboratory \\ Fuel Cycle Research and Development \\ Idaho Falls, Idaho 83415
}

http://www.inl.gov

Prepared for the

U.S. Department of Energy

Office of Nuclear Energy

Under DOE Idaho Operations Office

Contract DE-AC07-05ID14517 


\section{DISCLAIMER}

This information was prepared as an account of work sponsored by an agency of the U.S. Government. Neither the U.S. Government nor any agency thereof, nor any of their employees, makes any warranty, expressed or implied, or assumes any legal liability or responsibility for the accuracy, completeness, or usefulness, of any information, apparatus, product, or process disclosed, or represents that its use would not infringe privately owned rights. References herein to any specific commercial product, process, or service by trade name, trade mark, manufacturer, or otherwise, does not necessarily constitute or imply its endorsement, recommendation, or favoring by the U.S. Government or any agency thereof. The views and opinions of authors expressed herein do not necessarily state or reflect those of the U.S. Government or any agency thereof. 


\section{CONTENTS}

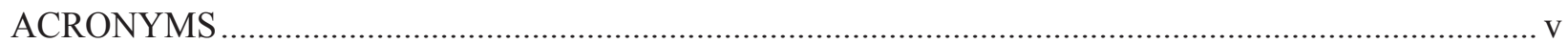

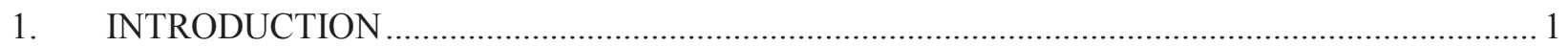

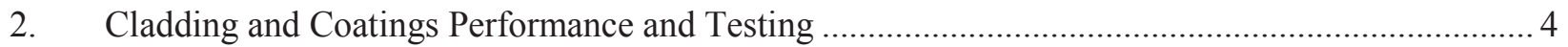

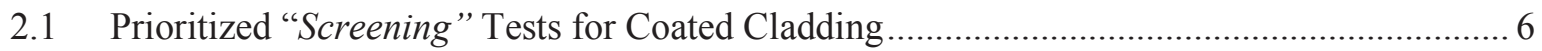

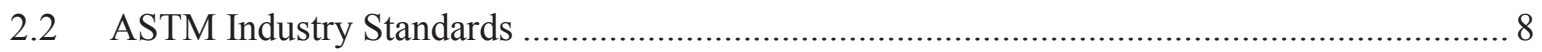

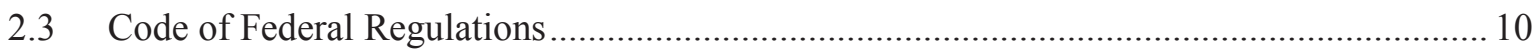

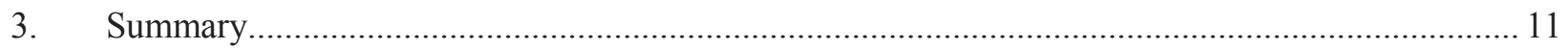

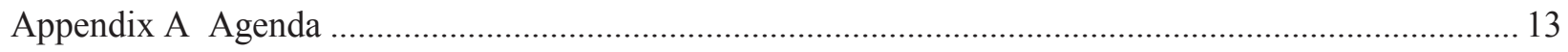

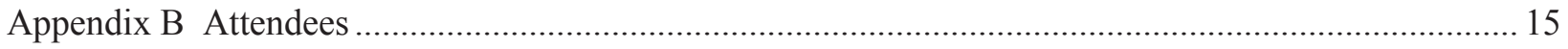

\section{FIGURES}

Figure 1. Near-term ATF Feasibility Assessment Activities .............................................................. 1

Figure 2. Key attributes for Enhanced Accident Tolerant Fuel; Circled Items Indicate Attributes Specific to Cladding. 5

\section{TABLES}

Table 1. Cladding and coatings initial test plan information. ...........................................................

Table 2. Guidance for Initial Pre-Screening Evaluation Tests - Under Normal Operating Conditions..

Table 3. Tests for Off-Normal Conditions (to prove enhanced ATF behavior) ........................................ 8

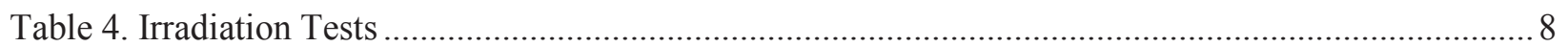




\section{ACRONYMS}

AFC Advanced Fuels Campaign

ANSI American National Standards Institute

ASTM American Society for Testing and Materials

ANSTO Australian Nuclear Science and Technology Organisation

ATF Accident Tolerant Fuel

ATR Advanced Test Reactor

BWR Boiling Water Reactor

CFR Code of Federal Regulations

DBA Design Basis Accident

DOE U.S. Department of Energy

FCRD Fuel Cycle Research and Development

FOA Funding Opportunity Announcement

INL Idaho National Laboratory

IRP Integrated Research Projects

LANL Los Alamos National Laboratory

LOCA loss-of-coolant accident

LWR Light Water Reactor

MOX molybdenum oxide

NEUP Nuclear Energy University Programs

NRC U.S. Nuclear Regulatory Commission

ORNL Oak Ridge National Laboratory

OSCC Outer Shim Control Cylinder

PDQ Post Quench Ductility

PWR Pressurized Water Reactor

R\&D research and development

SATS Severe Accident Test Station

TREAT Transient Reactor Test Facility

YSZ yttria-stabilized zirconia 


\section{ADVANCED FUELS CAMPAIGN CLADDING \& COATINGS MEETING SUMMARY}

\section{INTRODUCTION}

The Fuel Cycle Research and Development (FCRD) Advanced Fuels Campaign (AFC) organized a Cladding and Coatings operational meeting February 12-13, 2013, at Oak Ridge National Laboratory (ORNL). Representatives from the U.S. Department of Energy (DOE), national laboratories, industry, and universities attended the two-day meeting. The purpose of the meeting was to discuss advanced cladding and cladding coating research and development (R\&D); review experimental testing capabilities for assessing accident tolerant fuels; and review industry/university plans and experience in light water reactor (LWR) cladding and coating R\&D. Appendix A includes the meeting agenda and Appendix B includes the attendance list.

Advanced cladding and cladding coatings are one of the essential research areas for enhanced accident tolerant fuels (ATF) development. The definition of enhanced ATF is "Fuels with enhanced accident tolerance are those that, in comparison with the standard $\mathrm{UO}_{2}-$ Zircaloy system, can tolerate loss of active cooling in the core for a considerably longer time period (depending on the LWR system and accident scenario) while maintaining or improving the fuel performance during normal operations."

Jon Carmack, AFC National Technical Director welcomed everyone to the meeting and Frank Goldner, DOE AFC Federal Projector Director, discussed the R\&D strategy for Enhanced Accident Tolerant Fuels development. He presented the near term feasibility assessment schedule (see Figure 1) that shows the types of testing and analysis that could be used to enhance the R\&D cycle or to pre-screen initial concepts.

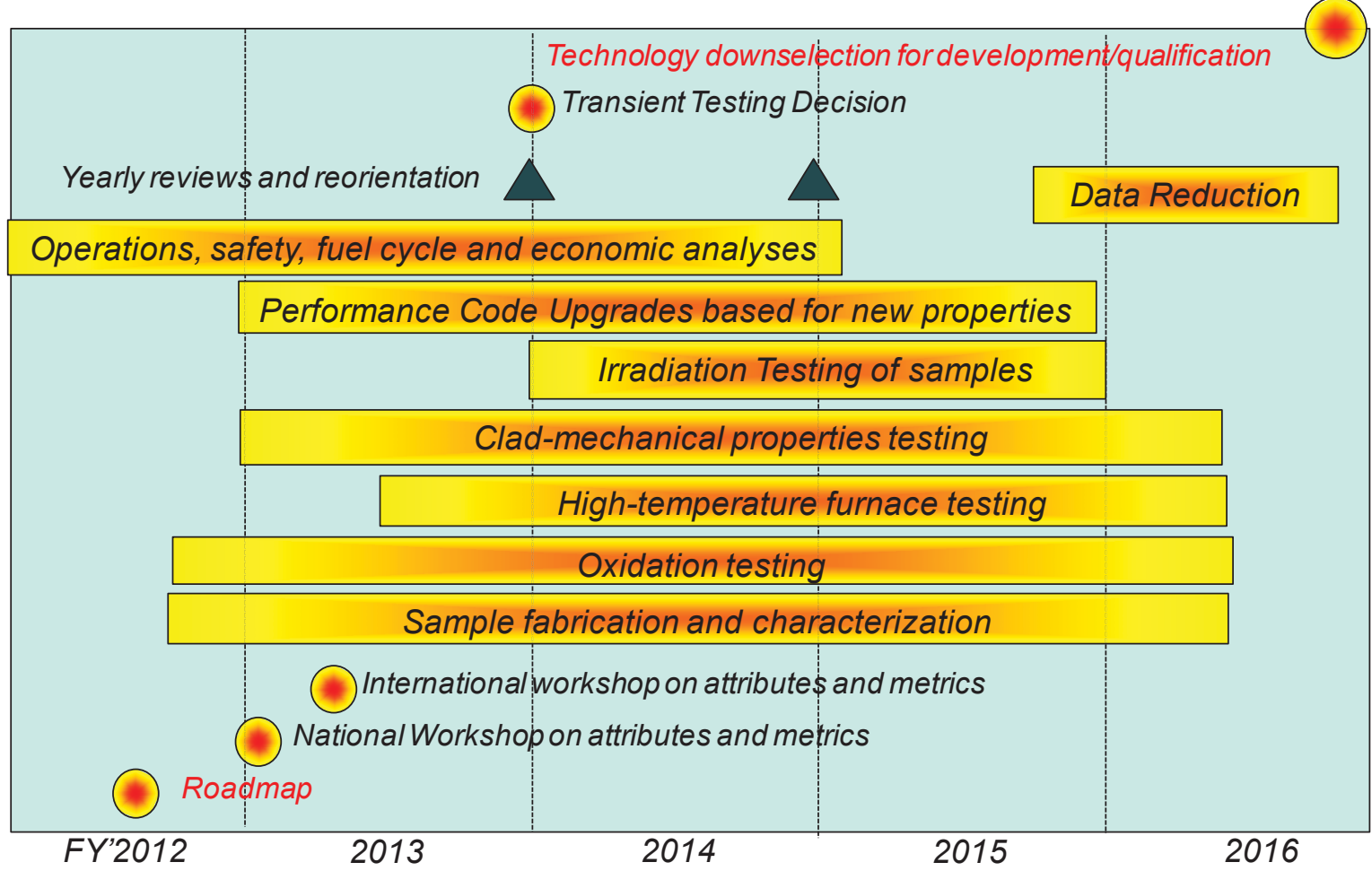

Figure 1. Near-term ATF Feasibility Assessment Activities 
The following list of desired meeting outcomes was presented. Each is addressed in the summary section of this report.

1. Understand the main considerations for proposed zirconium alloy coating concepts as candidates for being enhanced accident tolerant cladding candidates - what performance demonstration will qualify this concept?

2. Identification of Advanced Test Reactor (ATR) test environment parameters and requirements for a fuel/clad concept intended for reactor testing.

3. Agreement on an acceptable out of pile beyond design basis loss of coolant accident (LOCA) test sequence that can be used to qualify the coated zirconium alloy and other concepts for 2014 reactor testing (e.g. time, temperature, pressure, atmosphere).

4. Identification of concepts intended for ATR insertion in 2014 and planning to provide test material to INL in CY 2013.

Frank concluded his presentation by stating that the Accident Tolerant Fuel program is vibrant and highly visible. Ongoing studies in the U.S. are evaluating multiple fuels and cladding concepts. There is impressive collaboration among national laboratories, industry, and universities as well as growing international interest.

There are three major facilities being pursued as part of this initiative: the Severe Accident Test Station (2013); early irradiations in the Advanced Test Reactor (2014); and transient testing of fuels using the Idaho National Laboratory (INL) Transient Reactor Test Facility (TREAT; 2018). These experimental efforts are complemented by advanced modeling and simulation to better characterize expected fuel performance under transients. Additional research considers the design of a complete reactor system having enhanced severe accident tolerance versus focusing on the accident tolerance of the fuel system alone.

Informative presentations were made by national laboratory representatives to provide a status of cladding coating R\&D, an overview of the Enhanced Accident Tolerant LWR Fuels National Metrics Workshop in October 2012, ${ }^{1}$ irradiation testing of ATF concepts, and the use of the Severe Accident Test Facility.

Representatives from the three recently awarded Nuclear Energy University Programs (NEUP) Integrated Research Projects (IRP) and the three industry-led Funding Opportunity Announcement (FOA) research projects provided early updates on the status of their projects.

Each enhanced accident tolerant fuels development project, whether industry, university, or national laboratory, was asked to complete a "test plan" matrix designed to gather preliminary information on testing needs for each concept being developed. The key headings of the matrix are included in Table 1.

Table 1. Cladding and coatings initial test plan information.

\begin{tabular}{|l|l|l|l|l|}
\hline $\begin{array}{l}\text { Facilities required for } \\
\text { development / } \\
\text { fabrication / testing } \\
\text { (and when) }\end{array}$ & $\begin{array}{l}\text { What might be ready for reactor } \\
\text { insertion in mid-2014? (Coupons, } \\
\text { tubes, sealed tubes, materials only, } \\
\text { fueled rodlets, etc.) }\end{array}$ & $\begin{array}{l}\text { Planned post- } \\
\text { irradiation } \\
\text { analysis tasks }\end{array}$ & $\begin{array}{l}\text { Summary of } \\
\text { steps / path to } \\
\text { LTR/LTA }\end{array}$ & $\begin{array}{l}\text { Summary of } \\
\text { challenges and/or } \\
\text { technical risk for } \\
\text { concept }\end{array}$ \\
$\begin{array}{l}\text { Include tests planned, } \\
\text { where tests will be } \\
\text { conducted (industry } \\
\text { facility, university, DOE } \\
\text { laboratory, etc), and } \\
\text { approximate timeline. }\end{array}$ & $\begin{array}{l}\text { Note that design details would be } \\
\text { required by end of 2013. Please } \\
\text { indicate the primary goal of an in-pile } \\
\text { test if this is included in the test plan. } \\
\text { Other irradiation tests may be preferred } \\
\text { for some concepts. }\end{array}$ & & $\begin{array}{l}\text { Funding gaps or } \\
\text { challenges for the } \\
\text { existing tests } \\
\text { planned }\end{array}$ \\
\hline
\end{tabular}


A facilitated discussion was held on the second day of the meeting to validate the order and type of prescreening tests needed to demonstrate initial viability for enhanced accident tolerance and to identify the associated performance criteria.

- Review general classification of initial prescreening tests and validate the order.

- Define the performance demonstration metrics for the initial prescreening tests.

- Define the path forward to accident tolerant tests.

The industry-led FOA and university-led IRP teams are developing and evaluating both advanced cladding and advanced fuel concepts, in addition to one IRP team that is focusing on a complete reactor concept. The list below provides a brief introduction to each team and the key concepts of interest.

\section{FOA Teams}

- Westinghouse

- Research partners: General Atomics, Edison Welding Institute, Los Alamos National Laboratory (LANL), INL, Texas A\&M University, Massachusetts Institute of Technology, Southern Nuclear Operating Company

- Research overview:

- Cladding: Develop and test cladding concepts, such as $\mathrm{SiC}$ and $\mathrm{SiC}$ ceramic matrix composites or coated zirconium alloys

- Fuel: Develop and test high density / high thermal conductivity fuel pellets, such as Uranium nitride-uranium silicides

- $\underline{A R E V A}$

- Research partners: University of Wisconsin, University of Florida, Savannah River National Laboratory, Tennessee Valley Authority, Duke

- Research overview:

- Cladding: Investigating several coatings on Zirconium-alloy fuel claddings

- Fuel: Concepts include $\mathrm{UO}_{2}$ fuel with chromia dopant and the addition of $\mathrm{SiC}$ fibers to the doped pellets

- $\quad$ GE Global Research

- Research partners: Global Nuclear Fuels, University of Michigan, Los Alamos National Laboratory

- Research overview, cladding: Develop ferritic / martensitic alloy cladding (no fuel development)

\section{IRP Teams}

- University of Tennessee

- Research partners: Pennsylvania State University, University of Colorado, University of Michigan, LANL, Westinghouse, Oxford University, University of Manchester, 
University of Sheffield, University of Huddersfield, and the Australian Nuclear Science and Testing Organisation (ANSTO)

- Ceramic coatings for cladding (no fuel development), including:

- MAX phase ceramic coatings

- Graded interface architecture (multilayer) ceramic coatings, using yttriastabilized zirconia (YSZ) as the outer protective layer

- $\quad \underline{\text { University of Illinois }}$

- Research partners: University of Michigan, University of Florida, INL, University of Manchester, ATI Wah Chang

- Engineered Zirconium alloy cladding (no fuel development), including:

- Application of a coating layer

- Modification of the bulk cladding composition to promote precipitation of minor phase(s) during fabrication

- $\quad$ Georgia Institute of Technology

- Research partners:

- Collaborators: University of Michigan, Virginia Tech, University of Tennessee, University of Idaho, Morehouse College

- Foreign Involvement: Polytechnic University of Milan, University of Cambridge

- Industrial Participation: Westinghouse Electric, Southern Nuclear

- National Laboratory Participation: INL

- Integral Inherently Safe Light Water Reactor: High-power $(\sim 1,000 \mathrm{MWe}) \mathrm{LWR}$ with inherent safety features. The enabling innovations include the use of high power density technologies/components, a compact core design achieved by using a non-oxide fuel form with improved heat removal capability, combined with fuel/clad design of enhanced accident tolerance.

The following sections of this report document the outcome of the facilitated session.

\section{Cladding and Coatings Performance and Testing}

Early pre-screening tests must demonstrate that a concept improves on one or more of the key attributes provided in Figure 2 to be considered an "accident tolerant" fuel or cladding option that will then be recommended to move forward in the testing sequence. 


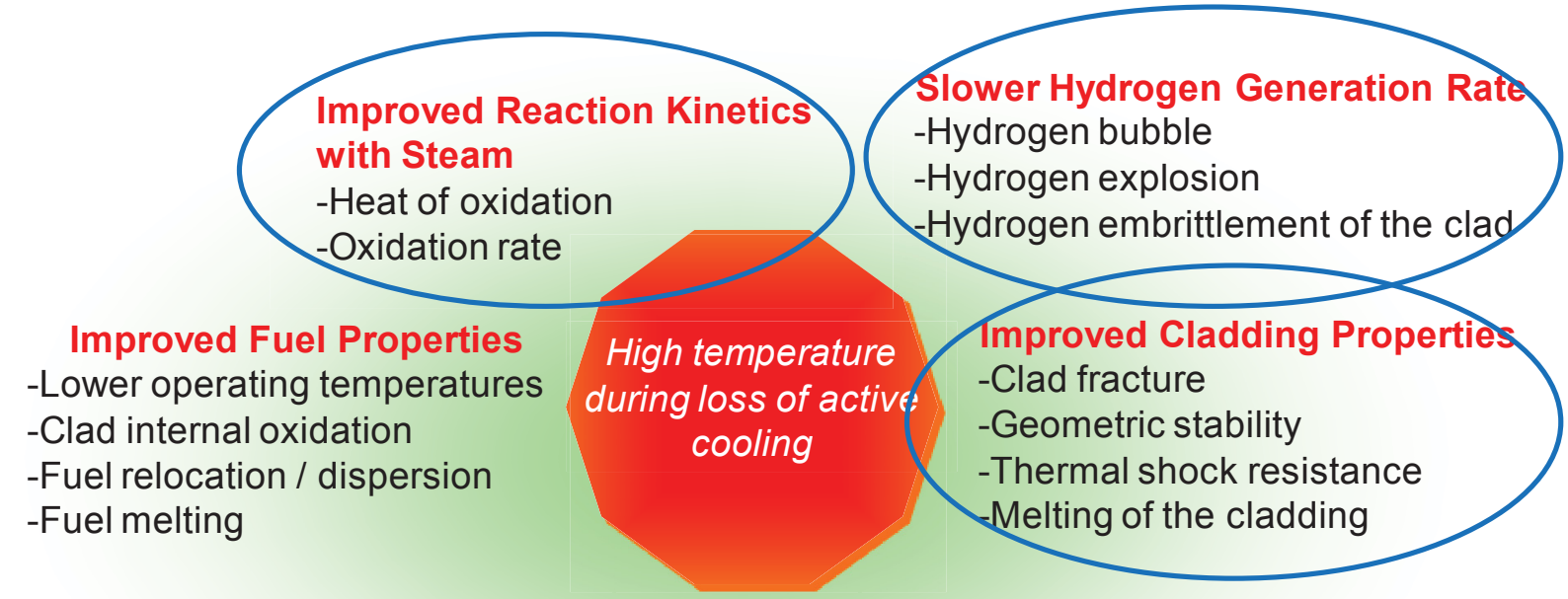

Enhanced Retention of Fission Products

-Gaseous fission products

-Solid/liquid fission products

Based on these safety-related issues, metrics for quantifying the enhancements in accident tolerance must be developed in conjunction with the safety features of a given LWR design and based on specific accident scenarios.

Figure 2. Key attributes for Enhanced Accident Tolerant Fuel; Circled Items Indicate Attributes Specific to Cladding.

Several key issues and assumptions were identified during the discussion period prior to identifying the preferred order of pre-screening tests.

\section{Assumptions}

- The coating or alternate cladding material under consideration does not negatively impact reactor performance (e.g. based on known properties, material considered meets basic requirements for use in a fuel pin).

- Concepts have been selected based on general material knowledge and initial computational analyses as part of the proposal process.

\section{Considerations/lssues}

- Determine how much coating will / should remain on the rod during normal handling, installation, normal operation and accident conditions.

- If coating flakes off due to erosion or corrosion processes, determine how the coating debris may affect the reactor during operation (assessed via corrosion/erosion tests, chemical compatibility tests, and computational analyses)

- Identify any non-desirable properties at the cladding / fuel interface (assessed via interdiffusion, porosity tests) 
- Coating adhesion to the substrate material can be assessed via a scratch test down to the coating cladding interface and/or an extreme bend test. The full depth scratch test may be overly conservative; strain tests or tests that simulate creep down should be considered.

- The ability to fully, consistently coat the cladding rod and endcaps and to evaluate the integrity and thickness of a coating may be exceedingly difficult. Coating techniques and evaluation tools must address this issue.

- Modeling or experimental demonstration is needed to determine the rate of oxidation in the substrate cladding tube after burn through of a $1 \%$ point exposure in the cladding coating. Modeling results will provide an estimate for coping time under severe accident conditions.

- A common cladding test that simulates severe accident conditions should be developed. Computational analyses should estimate the temperature gradient along the cladding during an accident; this gradient should be measured during severe accident test scenarios.

\section{Standard Environmental Conditions for Normal Operation Testing}

- $\quad$ PWR $-360^{\circ} \mathrm{C}$ Water at $2700 \mathrm{psi}$

- $\quad$ BWR $-400^{\circ} \mathrm{C}$ Water at 1500 psi steam

\subsection{Prioritized "Screening" Tests for Coated Cladding}

A set of prioritized screening tests for advanced cladding designs was proposed at the Enhanced Accident Tolerant LWR Fuels National Metrics Workshop in October 2012. ${ }^{1}$ This set of initially proposed tests was used as a starting point for the discussion on screening tests for coated cladding. Only minor adjustments were made to the proposed order of screening tests; the modified list of screening tests is provided below. The purpose of this set of preliminary tests is to show basic concept viability and to provide justification that the concept could meet the definition of "accident tolerant." Note that the series of tests listed assumes that basic fabrication constraints have been met. The fabrication processes required (e.g., fabrication temperatures, annealing, etc.) must be such that the substrate cladding material will retain sufficient corrosion resistance and mechanical properties.

1. Coating Adhesion - Address initial adhesion affect of thermal cycling and adhesion when exposed to coolant flow (spall) and wear (fretting); would likely include some mechanical testing to demonstrate adhesion (e.g., bend tests).

2. Environmental Testing - Address performance at temperature before and after a standardized scratch test (which may or may not expose the underlying substrate) and with a small exposed region (e.g. full depth scratch down to the substrate). Evaluations would include corrosion, erosion, stress corrosion cracking, etc., when exposed to LWR water over a range of chemistry conditions.

3. Chemical Compatibility - Address coating / substrate compatibility (establish temperature limit). For designs that deviate from a standard zirconium alloy substrate and $\mathrm{UO}_{2}$ fuel, compatibility between the fuel and substrate cladding material must also be demonstrated.

4. Severe Accident Conditions - Steam oxidation testing and measurement of post-steam ductility and strength.

5. Mechanical Tests - Assuming baseline unirradiated data already available, additional mechanical tests would not be required until after a cladding design has passed the other screening tests 
identified; for non-metallic substrate materials (e.g. ceramic substrate) mechanical tests may be performed earlier in the test series to determine ductility, fracture behavior, and hermeticity.

6. Irradiation Environmental Testing - Could include sample coupons first, followed by fueled cladding tubes; determine affect of irradiation on mechanical properties. Testing could entail ion irradiation in advance of neutron irradiation.

Table 2. Guidance for Initial Pre-Screening Evaluation Tests - Under Normal Operating Conditions

\begin{tabular}{|c|c|c|c|}
\hline Performance & Test & Condition & Analysis \\
\hline \multirow[t]{2}{*}{ Coating adhesion } & Autoclave without scratch & $\begin{array}{l}72 \text { hours } \\
\text { ASTM G2M (Base metal) } \\
400^{\circ} \mathrm{C} \text { pure water/dry } \\
\text { steam } \\
1500 \text { psi }\end{array}$ & $\begin{array}{l}\text { Visual } \\
\text { Weight change } \\
\text { Recommendation: Consider } \\
\text { performing tests based on } \\
\text { this ASTM standard. The } \\
\text { goal is to justify cladding } \\
\text { performance to move } \\
\text { forward. }\end{array}$ \\
\hline & $\begin{array}{l}\text { Address scratch tests per } \\
\text { ASTM Standards }\end{array}$ & $\begin{array}{l}\text { ASTM C1624 for ceramic } \\
\text { coatings }\end{array}$ & \\
\hline $\begin{array}{l}\text { Adhesion, } \\
\text { Strength, and } \\
\text { Ductility }\end{array}$ & $\begin{array}{l}\text { Mechanical Adhesion Test } \\
\text { Options for consideration } \\
\text { Bend Test-performance at } \\
\text { various or increasing angles. } \\
\text { How and when does it fail? } \\
\text { Burst test } \\
\text { Tensile test } \\
\text { Creep test } \\
\text { Pressurized tube } \\
\text { Thermal cycling } \\
\text { Coupon tests or coated tubing }\end{array}$ & $\begin{array}{l}\text { Survive a } 1 \% \text { strain } \\
\text { ASTM C } 633 \text { adhesion, } \\
\text { cohesion, strength of } \\
\text { thermal sprays and } \\
\text { coatings } \\
\text { ASTM D4541-09E1 } \\
\text { Strength of coatings using } \\
\text { a portable tester }\end{array}$ & $\begin{array}{l}\text { Determine the failure mode } \\
\text { and strain at which failure } \\
\text { occurs. } \\
\text { When does catastrophic } \\
\text { failure occur? }\end{array}$ \\
\hline Compatibility & $\begin{array}{l}\text { Chemical compatibility } \\
\text { Thermal interdiffusion between } \\
\text { coating and substrate } \\
\text { Coolant compatibility }\end{array}$ & $\begin{array}{l}400^{\circ} \mathrm{C}-450^{\circ} \mathrm{C} \text { water } / \mathrm{dry} \\
\text { steam with relevant } \\
\text { chemistry }\end{array}$ & $\begin{array}{l}\text { Consider assessment of } \\
\text { hydrogen pickup; NRC ppm } \\
\mathrm{H}_{2} \text { limits are material } \\
\text { specific (alloy dependent) } \\
\text { Hydride issue } \\
\text { Licensing issue } \\
\text { Zirconium issue }\end{array}$ \\
\hline
\end{tabular}


Table 3. Tests for Off-Normal Conditions (to prove enhanced ATF behavior)

\begin{tabular}{|l|l|l|}
\hline \multicolumn{1}{|c|}{ Test } & \multicolumn{1}{|c|}{ Condition } & \multicolumn{1}{c|}{ Analysis } \\
\hline Simulated LOCA Test & $\begin{array}{l}<17 \% \text { oxidation at } 1200^{\circ} \mathrm{C} \text { for } 400 \\
\text { seconds }\end{array}$ & $\begin{array}{l}\text { Weight change or cross-section } \\
\text { Porosity } \\
\text { Post Quench Ductility Test (PQD) } \\
\text { Prove better performance than } \\
\text { existing fuel/cladding }\end{array}$ \\
\hline $\begin{array}{l}\text { Incremental Temperature Increase } \\
\text { Test }\end{array}$ & $\begin{array}{l}\text { Use existing standard for current } \\
\text { alloys, 10CFR50.46B, for guidance } \\
\text { Raise steam temperature } \\
\text { incrementally until failure; } \\
\text { document process }\end{array}$ & Determine mode and time of failure \\
\hline
\end{tabular}

Table 4. Irradiation Tests

\begin{tabular}{|l|l|l|}
\hline \multicolumn{1}{|c|}{ Test } & \multicolumn{1}{|c|}{ Condition } & \multicolumn{1}{c|}{ Analysis } \\
\hline Ion Irradiation & $\begin{array}{l}\text { Introduce damage via ion irradiation } \\
\text { for initial (lower cost) assessment of } \\
\text { behavior under irradiation }\end{array}$ & $\begin{array}{l}\text { Microstructural analysis } \\
\text { Coating adhesion } \\
\text { Assessment of compatibility }\end{array}$ \\
\hline Reactor - Steady state & $\begin{array}{l}\text { Initial neutron irradiation of } \\
\text { cladding coupons or tubes, with or } \\
\text { without fuel, in a drop-in capsule }\end{array}$ & $\begin{array}{l}\text { Microstructural analysis } \\
\text { Coating adhesion } \\
\text { Assessment of compatibility }\end{array}$ \\
\hline Reactor - Loop test & $\begin{array}{l}\text { Neutron irradiation of cladding } \\
\text { coupons or tubes with flowing } \\
\text { coolant (e.g. loop test) }\end{array}$ & $\begin{array}{l}\text { Microstructural analysis } \\
\text { Coating adhesion } \\
\text { Assessment of compatibility }\end{array}$ \\
\hline Reactor - Transient testing & To be determined & \\
\hline
\end{tabular}

\subsection{ASTM Industry Standards}

New research concepts for enhanced ATF are not limited by current industry standards, but these standards can be used as solid guidance in the development of new concepts:

\section{- D5139-12, Standard Specification for Sample Preparation for Qualification Testing of Coatings to be Used in Nuclear Power Plants.}

This specification defines the size composition and surface preparation requirements for the preparation of test samples used for qualification testing of coatings utilized in nuclear power plant construction and maintenance. All panels should be carbon steel. Materials shall be tested for abrasion, and shall conform to specified requirements of steel samples, and concrete blocks.

\section{- D5144-08e1, Standard Guide for Use of Protective Coating Standards in Nuclear Power} Plants.

This guide addresses the concerns of Regulation Guide 1.54 and USNRC Standard Review Plan 6.1.2, and the replacement of ANSI Standards N5.12, N101.2, and N101.4. This guide covers coating work on previously coated surfaces as well as bare substrates. This guide applies to all coating work in Coating Service Level I and III areas (that is, safety-related coating work). Applicable sections of this guide may also be used to evaluate and select protective coatings for Coating Service Level II areas where deemed appropriate by the licensee. 
- D3911-08, Standard Test Method for Evaluating Coatings Used in Light-Water Nuclear Power Plants at Simulated Design Basis Accident (DBA) Conditions.

This test method is designed to provide a uniform test to determine the suitability of Coating Service Level 1 coatings used inside primary containment of light-water nuclear facilities under simulated DBA conditions. This test method is intended only to demonstrate that under DBA conditions, the coatings will remain intact and not form debris which could unacceptably compromise the operability of engineered safety systems. Deviations in actual surface preparation and in application and curing of the coating materials from qualification test parameters require an engineering evaluation to determine if additional testing is required.

- C633 - 01(2008), Standard Test Method for Adhesion or Cohesion Strength of Thermal Spray Coatings.

This test method is useful for comparing adhesion or cohesion strengths of coatings of similar types of thermal spray materials. The test should not be considered to provide an intrinsic value for direct use in making calculations, such as to determine if a coating will withstand specific environmental stresses. Because of residual stresses in thermal spray coatings, actual strength depends upon the shape of the particular coated part. Also, in use, a coating may be stressed in a more complex manner than is practical for a standard test. It is expected that testing per ASTM C633 will provide primary data on adhesion of thermal spray coatings as it gives a quantitative measurement of adhesion strength that can then be interpreted in conjunction with the failure analysis of the test sample, i.e. where the failure occurred, at the adhesive to coating interface/in the coating itself/at the coating-substrate interface. Semi-quantitative comparison of coating options should be possible.

- C1624 - 05(2010), Standard Test Method for Adhesion Strength and Mechanical Failure Modes of Ceramic Coatings by Quantitative Single Point Scratch Testing.

This test is intended to assess the mechanical integrity, failure modes, and practical adhesion strength of a specific hard ceramic coating on a given metal or ceramic substrate. The test method does not measure the fundamental "adhesion strength" of the bond between the coating and the substrate. Rather, the test method gives a quantitative engineering measurement of the practical (extrinsic) adhesion strength and damage resistance of the coating-substrate system as a function of applied normal force. The adhesion strength and damage modes depend on the complex interaction of the coating/substrate properties (hardness, fracture strength, modulus of elasticity, damage mechanisms, microstructure, flaw population, surface roughness, and so forth) and the test parameters (stylus properties and geometry, loading rate, displacement rate, and so forth).

- ASTM G2M-88(1996)e1, Standard Test Method for Corrosion Testing of Products of Zirconium, Hafnium, and Their Alloys in Water at $633^{\circ} \mathrm{K}$ or in Steam at $673^{\circ} \mathrm{K}$ [Metric] (Withdrawn 2005).

Withdrawn Rationale: This test method covers (1) the determination of mass gain and (2) the surface inspection of products of zirconium, hafnium, and their alloys when corrosion tested in water at $633 \mathrm{~K}$ or in steam at $673 \mathrm{~K}$. Formerly under the jurisdiction of Committee G01 on Corrosion of Metals, this test method was withdrawn in January 2005 for failure to update within the 8-year period.

- D4541 - 09e1, Standard Test Method for Pull-Off Strength of Coatings Using Portable Adhesion Testers. 
The pull-off strength of a coating is an important performance property that has been used in specifications. This test method serves as a means for uniformly preparing and testing coated surfaces, and evaluating and reporting the results. This test method is applicable to any portable apparatus meeting the basic requirements for determining the pull-off strength of a coating.

Variations in results obtained using different devices or different substrates with the same coating are possible (see Section 11). Therefore, it is recommended that the type of apparatus and the substrate be mutually agreed upon between the interested parties.

The purchaser or specifier shall designate a specific test method, that is, B, C, D, E, or F when calling out this standard.

\subsection{Code of Federal Regulations}

The following regulation applies to new research concepts for enhanced ATF concepts:

\section{- 10CFR50.46, Acceptance criteria for emergency core cooling systems for light-water} nuclear power reactors.

b)(1) Peak cladding temperature. The calculated maximum fuel element cladding temperature shall not exceed $2200^{\circ} \mathrm{F}\left(1204^{\circ} \mathrm{C}\right)$.

(2) Maximum cladding oxidation. The calculated total oxidation of the cladding shall nowhere exceed 0.17 times the total cladding thickness before oxidation. As used in this subparagraph total oxidation means the total thickness of cladding metal that would be locally converted to oxide if all the oxygen absorbed by and reacted with the cladding locally were converted to stoichiometric zirconium dioxide. If cladding rupture is calculated to occur, the inside surfaces of the cladding shall be included in the oxidation, beginning at the calculated time of rupture. Cladding thickness before oxidation means the radial distance from inside to outside the cladding, after any calculated rupture or swelling has occurred but before significant oxidation. Where the calculated conditions of transient pressure and temperature lead to a prediction of cladding swelling, with or without cladding rupture, the unoxidized cladding thickness shall be defined as the cladding cross-sectional area, taken at a horizontal plane at the elevation of the rupture, if it occurs, or at the elevation of the highest cladding temperature if no rupture is calculated to occur, divided by the average circumference at that elevation. For ruptured cladding the circumference does not include the rupture opening.

(3) Maximum hydrogen generation. The calculated total amount of hydrogen generated from the chemical reaction of the cladding with water or steam shall not exceed 0.01 times the hypothetical amount that would be generated if all of the metal in the cladding cylinders surrounding the fuel, excluding the cladding surrounding the plenum volume, were to react.

(4) Coolable geometry. Calculated changes in core geometry shall be such that the core remains amenable to cooling.

(5) Long-term cooling. After any calculated successful initial operation of the ECCS, the calculated core temperature shall be maintained at an acceptably low value and decay heat shall be removed for the extended period of time required by the long-lived radioactivity remaining in the core. 


\section{Summary}

The following list of desired meeting outcomes was presented in the introduction to this meeting report. The current status of achieving those outcomes is summarized below.

1. Understand the main considerations for proposed zirconium alloy coating concepts as candidates for being enhanced accident tolerant cladding candidates. What performance demonstration will qualify this concept?

a. A series of tests was defined for analysis of ATF concepts under investigation. The following test categories were defined:

- Prioritized initial screening tests under normal operations

- Tests to determine performance under simulated accident conditions - e.g. Severe Accident Test Station (SATS) (high temperature, pressure, temperature thermogravimetry; and integral LOCA module)

- Performance tests under radiation - normal operations

- Performance tests under radiation - transient conditions (e.g. TREAT testing)

b. Requirements for testing ATF Candidate Concepts in SATS

- Urania fuel / zirconium alloy cladding must perform satisfactorily under normal operating and design basis accident conditions $\left(1200^{\circ} \mathrm{C}\right)$.

- Candidate materials should be mechanically sound and be provided with clear pedigree.

- Tests at SATS will be focused on examining behavior of candidate concepts under beyond design basis accident conditions $\left(>1200^{\circ} \mathrm{C}\right)$.

- It is necessary that superior behavior of the proposed concepts under normal and design basis accident conditions be demonstrated to the best extent possible.

2. Identify ATR test environment parameters and requirements for a fuel/clad concept intended for reactor testing.

a. Requirements for 2014 ATR Test

- Sealed rodlets

- Double encapsulated

b. Capsule design is based on previous ATR-MOX test assemblies

- 9 individually encapsulated rodlets

- Insertion into small-I positions

- Accommodates 6.0-in fuel column, but can use less; provides ample plenum volume for gas release

- Prototypic (W17x17) cladding diameter 
- $\quad 0.327$-in ID by 0.379 -in OD

c. ATR-MOX test assembly design

- Aluminum, 316SS or Inconel baskets

- 3 stacks of 3 rodlets in triangular array

- Flux monitors incorporated

d. Small-I Positions

- Small-I relatively insensitive to outer shim control cylinder (OSCC) rotation $(\sim 4 \%)$

- FCRD has reserved I-22, I-23, and I-24 beginning in Cycle 157A (February 2014)

3. Agree on an acceptable out of pile beyond design basis LOCA test sequence that can be used to qualify the coated zirconium alloy and other concepts for 2014 reactor testing (e.g. time, temperature, pressure, and atmosphere). Guidelines for normal conditions and accident test sequences can be found in the following:

a. Normal Operation Guidelines: ASTM and CFR standards

b. Accident Conditions: NRC, ASTM, and CFRs

4. Identify concepts intended for ATR insertion in 2014 and a plan to provide test material to INL in CY 2013. ATF concepts currently under investigation were identified and summarized in an overall concept matrix. This matrix further defines proposed test sequences and potential readiness for FY14 ATR insertion. Lead organizations for each ATF concept are defined below. All parties have interest in pursuing ATR irradiation in FY14 with the exception of University of Tennessee (per project lead, K. Sickafus).

a. FOAs: AREVA, Westinghouse, GE

b. IRPs: University of Illinois, Georgia Institute of Technology, University of Tennessee (NOT ready for FY14 insertion per Kurt Sickafus)

c. National Laboratories: LANL, ORNL

\section{References}

1. Braase, Lori, "Enhanced Accident Tolerant LWRS National Metrics Workshop Report," January 2013, INL/EXT-13-28090, FCRD-FUEL-2013-000087 


\section{Appendix A}

\section{Agenda}




\section{Appendix A \\ Agenda}

\section{AGENDA}

Tuesday, February 12, 2013

\begin{tabular}{|c|c|c|}
\hline $8: 30$ & Welcome / Introductions & Jon Carmack \\
\hline $8: 40$ & Program Status/DOE Perspective & Frank Goldner \\
\hline $9: 00$ & Cladding Coating R\&D in the AFC & Stu Maloy \\
\hline $9: 30$ & $\begin{array}{l}\text { Review of Coating Performance and Attributes Identified in } \\
\text { National Metrics review meeting }\end{array}$ & Shannon Bragg-Sitton \\
\hline 10:00 & Break & \\
\hline $10: 30$ & $\begin{array}{l}\text { Survivability of Cladding and Use of Severe Accident Test } \\
\text { Facility }\end{array}$ & Lance Snead \\
\hline $11: 00$ & Testing of ATF concepts in ATR & Steven Hayes \\
\hline $11: 30$ & Working Lunch: Cladding-Coatings Test Matrix Review & Shannon Bragg-Sitton \\
\hline $\begin{array}{l}1: 00 \\
1: 45\end{array}$ & $\begin{array}{l}\text { Westinghouse Experience on cladding coating R\&D } \\
\text { GE Perspective on cladding coating technology }\end{array}$ & $\begin{array}{l}\text { Ed Lahoda } \\
\text { Raul Rebak }\end{array}$ \\
\hline $2: 30$ & Break & \\
\hline $\begin{array}{l}3: 00 \\
3: 30 \\
4: 00 \\
4: 30\end{array}$ & $\begin{array}{l}\text { AREVA cladding coating R\&D perspective } \\
\text { Illinois IRP cladding coating R\&D plans } \\
\text { Georgia Tech IRP } \\
\text { University of Tennessee IRP cladding coating R\&D plans }\end{array}$ & $\begin{array}{l}\text { Kevin McCoy } \\
\text { Brent Heuser } \\
\text { Bojan Petrovic } \\
\text { Kurt Sickafus }\end{array}$ \\
\hline $5: 00$ & Adjourn & \\
\hline
\end{tabular}

Wednesday, February 13, 2013

\section{AGENDA}

8:30 Discuss and validate the order of the pre-screening tests for the initial cladding and coating concepts

10:00 Discuss test methods and metrics to be used for assessing cladding coating performance

12:00 Working Lunch: Consensus on acceptable out-of-pile beyond design basis LOCA test sequence to qualify coated zircaloy and other concepts. 


\section{Appendix B}

\section{Attendees}




\section{Appendix B}

\section{Cladding \& Coatings Meeting Attendance}

\begin{tabular}{|c|c|c|c|c|c|}
\hline First & Last & Phone & Email & Role & Org \\
\hline Gary & Bell & $865-241-4400$ & bellgl@ornl.gov & $\begin{array}{l}\text { Oxide Fuel / } \\
\text { Irradiations }\end{array}$ & ORNL \\
\hline Theodore & Besmann & $865-574-6852$ & besmanntm@ornl.gov & ATF Fuel Dev & ORNL \\
\hline Lori & Braase & $208-526-7763$ & lori.braase@inl.gov & AFC Coordinator & INL \\
\hline Shannon & Bragg-Sitton & $208-526-2367$ & $\begin{array}{l}\text { shannon.bragg- } \\
\text { sitton@inl.gov }\end{array}$ & LWR / ATF Fuels & INL \\
\hline TS & Byun & $865-576-7738$ & byunts@ornl.gov & $\begin{array}{l}\text { Materials Science \& } \\
\text { Tech }\end{array}$ & ORNL \\
\hline Jon & Carmack & $208-533-7255$ & jon.carmack@inl.gov & AFC NTD & INL \\
\hline Bo & Cheng & & bcheng@epri.com & EPRI Fuel & EPRI \\
\hline Peter & Chou & & pchou@epri.com & & EPRI \\
\hline Chaitanya & Deo & & chaitanya.deo@gatech.edu & IRP & GATECH \\
\hline Mitch & Farmer & $630-252-4539$ & farmer@anl.gov & ATF Metrics & ANL \\
\hline Kevin & Field & & fieldkg@ornl.gov & $\begin{array}{l}\text { Cladding } \\
\text { Characterization }\end{array}$ & ORNL \\
\hline Frank & Goldner & $301903-3346$ & $\begin{array}{l}\text { frank.goldner@nuclear.energ } \\
\text { y.gov }\end{array}$ & $\begin{array}{l}\text { Federal Campaign } \\
\text { Manager }\end{array}$ & US DOE \\
\hline Steven & Hayes & $208-526-7255$ & steven.hayes@inl.gov & Irradiation Testing & INL \\
\hline Brent & Heuser & $217-333-9610$ & bheuser@illinois.edu & $\begin{array}{l}\text { IRP- Engineered } \\
\text { Zircaloy Cladding } \\
\text { Mods for ATF }\end{array}$ & $\begin{array}{l}\mathrm{U} \text { of } \\
\text { Illinois }\end{array}$ \\
\hline Dave & Hoelzer & $865-574-5096$ & hoelzerd@ornl.gov & Advanced Materials & ORNL \\
\hline
\end{tabular}




\begin{tabular}{|c|c|c|c|c|c|}
\hline First & Last & Phone & Email & Role & Org \\
\hline Edward & Lahoda & $412-874-2887$ & lahodaej@westinghouse.com & $\begin{array}{l}\text { Fuel Cycle } \\
\text { Optimization } \\
\text { Westinghouse } \\
\text { Electric }\end{array}$ & $\begin{array}{l}\text { Westing- } \\
\text { house }\end{array}$ \\
\hline Stuart & Maloy & $505-667-9784$ & maloy@lanl.gov & Core Materials Tech & LANL \\
\hline Kevin & McCoy & $434-832-2668$ & kevin.mccoy@areva.com & Industry FOA & AREVA \\
\hline Don & McGee & $704-805-2576$ & donald.mcgee@areva.com & PM EATF & AREVA \\
\hline Andrew & Nelson & $505-667-1268$ & atnelson@lanl.gov & Ceramic Fuels & LANL \\
\hline Bojan & Petrovic & $404-894-8173$ & bojan.petrovic@gatech.edu & $\begin{array}{l}\text { IRP - Integral } \\
\text { Inherently Safe } \\
\text { LWR }\end{array}$ & GATECH \\
\hline Bruce & Pint & $865-576-2897$ & pintba@ornl.gov & & ORNL \\
\hline Jeff & Powers & & powersjj@ornl.gov & $\begin{array}{l}\text { Microencapsulated } \\
\text { Fuels }\end{array}$ & ORNL \\
\hline Raul & Rebak & & rebak@ge.com & Industry Rep - FOA & GE \\
\hline Kurt & Sickafus & $865-974-4858$ & kurt@utk.edu & $\begin{array}{l}\text { IRP - Ceramic } \\
\text { Coatings for } \\
\text { Cladding }\end{array}$ & UTK \\
\hline Lance & Snead & $865-574-9942$ & sneadll@ornl.gov & $\begin{array}{l}\text { Microencapsulated } \\
\text { Fuels }\end{array}$ & ORNL \\
\hline Kurt & Terrani & $865-576-0264$ & terranika@ornl.gov & Fuel Development & ORNL \\
\hline Yong & Yan & & yy9@ornl.gov & Accident Testing & ORNL \\
\hline
\end{tabular}

